\title{
Adsorption of Diazo Dye C.I. Acid Red 97 from Aqueous Solution onto Yemen Natural Clay: Equilibrium and Thermodynamic Studies
}

\author{
Abdulrakib Al-Wahbi* \\ Chemical Engineering Department, Faculty of Petroleum and Engineering, Hadramout University, Al-Mukalla, Hadramout, Republic of Yemen
}

\begin{abstract}
The equilibrium adsorption of diazo dye C.I. Acid Red 97 (AR97) from aqueous solutions onto Yemen natural clay has been studied as a function of temperature and particle size range. The equilibrium data were correlated using Langmuir, Fruendlich, Temkin, Redlich-Peterson, and Sips isotherm models. Thermodynamic parameters such as standard enthalpy $\left(\Delta H^{\circ}\right)$, standard entropy $\left(\Delta S^{\circ}\right)$ and standard Gibbs free energy $\left(\Delta G^{\circ}\right)$ were calculated. It was found that the adsorption capacity of clay for AR97 decreases with increasing temperature and particle size range. The results show that Fruendlich and Sips isotherm models best fit the experimental data over the whole concentration range. The maximum adsorption capacity for Yemen natural clay was $196.7\left(\mathrm{mg} . \mathrm{g}^{-1}\right)$. The value of $\Delta \mathrm{H}^{0}$ was $-20.5(\mathrm{~kJ} . \mathrm{g}$-mol-1) indicating that the adsorption of AR79 onto Yemen natural clay is characterized by physical adsorption. $\Delta \mathrm{G}^{\circ}$ values obtained were all negatives indicating a spontaneous adsorption process.
\end{abstract}

Keywords: Diazo dye, Adsorption, Yemen Natural Clay, Langmuir, Fruendlich, Temkin, Redlich-Peterson, isotherm models

\section{Introduction}

Many industries, such as textiles, pulp mills, leather, printing, food, and plastics, use dyes in order to color their products and consume substantial volumes of water. The presence of very small amounts of dyes in water (less than $1 \mathrm{ppm}$ for some dyes) is highly visible and undesirable (Robinson et al. 2001, Banat et al. 1996). As a result; they generate a considerable amount of colored wastewater. It is recognized that public perception of water quality is greatly influenced by the color. Over 100,000 commercially available synthesis dyes exist and more than $7 \times 10^{5}$ tons per year are produced annually (Yener et al. 2008). Azo dyes are an important class of synthetic dyes and used as coloring agents in the textile, paint, ink and plastic industries, accounting for $50 \%$ of all commercial dyes (Zollinger, H., 1991). Azo dyes, containing one or more azo bond ( $-\mathrm{N}=\mathrm{N}-)$, account for $60-70 \%$ of all textile dyestuffs used (Carliell et al. 1995). Large amounts of these dyes remain in the effluent after the completion of dyeing process. Due to their stable and complex composition, high toxicity, poor degradability, great solubility in water, difficulty of treatment in the biological treating station, and because of their association with various human health problems, Azo dyes have been considered as an extremely important pollutants in the environment and received considerable attention (Ramakrishna et al. 1997, Vandevivere et al. 1998, Robinson et al. 2002, and Baughman and Weber 1994). Hence, it becomes imperative that azo dyes are to be removed from the effluents before it is disposed. Among various treatment technologies, adsorption onto activated carbon proved to be one of the most effective and reliable physicochemical treatment methods (El Qada et al. 2007, Chan et al. 2009, El Nemr et al. 2009 and Gad and El-Sayed 2009). However, the overlying cost of activated carbon and its regeneration problems led researchers to produce and use low-cost, abundance, and not need to regeneration adsorbents.

Clay materials have been increasingly paid attention because of their low cost, abundance in most continents of the world, high specific surface area, and chemical and mechanical stabilities. In addition, Clay materials have shown good results as an adsorbent for the removal of various metals ( Bhattacharyya and Gupta, 2008) surfactants (Rao and He, 2006), and basic and acid dyes (Bulut et al. 2008, Dögan, 2009 and Branuer et al. 1938).

Up to our knowledge, no research has been conducted using Yemen natural clay for adsorption Diazo Dye C.I. Acid Red 97. Therefore, the main aim of this study is to investigate the suitability of Yemen natural clay as low-cost adsorbent for the removal of diazo dye C.I. Acid Red 97.

Received on July 14, 2018; accepted on August 20, 2018

Correspondence concerning this article should be addressed to Abdulrakib A. Al-Wahbi, email: Abdalwahby_73@yahoo.com. 


\section{Materials and Methods}

\subsection{Materials}

The natural clay used in this work was collected from Al-Rayan zone, Al-Mukalla City, Hadramout Governorate, Republic of Yemen. The adsorbent was washed, crushed and sieved through different standard sieves into the desired particle size and used without any pretreatment. The resulting sample was dried at $105^{\circ} \mathrm{C}$ and stored in sealed containers prior to use. Diazo dye [C.I. Acid Red 97(AR97), $\lambda \max : 498 \mathrm{~nm}$ ] supplied by Techno Color Corporation (Bombay, India) was used as principal adsorbate. Chemical structure of dye is shown in Figure 1.

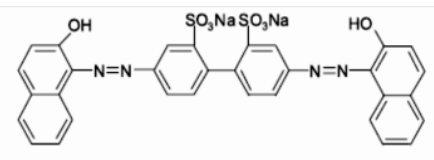

Fig. 1 Chemical Structure of Acid Red 97.

\subsection{Characterization of Natural Clay}

Chemical composition of natural clay was obtained using XRF Spectrometer, ARL 9800, Switzerland. Solid density, particle density and porosity for natural clay were obtained using mercury Poresizer 9320, Micromertics, USA. The surface physical properties such as specific surface area, pore size distribution and total pore volume were measured by nitrogen adsorption-desorption isotherms using a multipurpose apparatus Nova 2000 analyzer, Quantachrome Instruments, Japan. A BET analysis from the amount of $\mathrm{N}_{2}$ gas adsorbed at various partial pressures (five points $0.05<\mathrm{p} / \mathrm{p}_{0}<0.3$, nitrogen molecular cross-sectional area $=0.162 \mathrm{~nm}^{2}$ ) was used to determine the surface area $(\mathrm{SBET})$, and a single condensation point $\left(\mathrm{p} / \mathrm{p}_{0}=0.95\right)$ was used to find the total pore volume $(\mathrm{VT})$. The average pore radius (rav) was calculated using total surface area and total pore volume ( $\mathrm{rav}=2 \mathrm{VT} / \mathrm{SBET})$. The volumes of micropores, mesopores, and macropores were calculated from $\mathrm{N}_{2}$ adsorption isotherm by applying the Barrett Joyner-Hallenda (BJH) method (Barrett 1951). Mineralogical analysis (XRD analysis) was obtained using Panalytical X'Pert PRO X-ray diffractometer.

\subsection{Experimental}

Batch adsorption experiments were carried out using bottle-point method (El-Geundi, 1990). A stock solution of AR97 (1000 mg.dm ${ }^{-3}$ ) was prepared and was subsequently diluted to the required initial concentrations. Adsorption capacity of the clay towards AR97 was determined by contacting a constant mass $(0.1 \mathrm{~g})$ of clay with a fixed volume $(50 \mathrm{ml})$ in sealed glass bottles of different initial concentrations (25-600 mg.dm-3) of dye solution at $\mathrm{pH} 5 \pm 0.2$. The bottles were agitated in an isothermal water-bath shaker for $5 \mathrm{~h}$ until equilibrium was reached. At the end of the adsorption time, a known volume of the solution was removed and centrifuged for analysis of the supernatant. Calibration curve for AR97 was prepared by recording the absorbance values for a range of known concentrations of dye solution and the maximum absorbance was determined $(\lambda \max =498 \mathrm{~nm}$ ). The value of $\lambda \max$ was used in all subsequent investigations using this dye. The concentration of AR97 in aqueous solution was then determined at $\lambda \max =498 \mathrm{~nm}$ using double beam UV-visible spectrophotometer (Shimadzu, Model UV 1601, Japan). The amount of AR97 adsorbed onto clay, $q_{\mathrm{e}}\left(\mathrm{mg} . \mathrm{g}^{-1}\right.$ ), was calculated by the following equation

$\mathrm{q}_{\mathrm{e}}=\frac{\left(\mathrm{C}_{\mathrm{o}}-\mathrm{C}_{\mathrm{e}}\right)}{\mathrm{m}} * \mathrm{~V}$

\section{Results and Discussion}

\subsection{Characterization of Natural Clay}

Chemical analysis indicates the following composition: $\mathrm{SiO}_{2}, 62.38 \%$; $\mathrm{Al}_{2} \mathrm{O}_{3}, 13.60 \% ; \mathrm{Fe}_{2} \mathrm{O}_{3}, 7.05 \%$; $\mathrm{CaO}, 3.75 \% ; \mathrm{MgO}, 3.11 \% ; \mathrm{K}_{2} \mathrm{O}, 2.63 \%$. The ratio $\mathrm{SiO}_{2}: \mathrm{Al}_{2} \mathrm{O}_{3}$ is 4.598 , which is higher than that of pure montmorillonite (2.81:1), (El-Geundi, 1990). The $\mathrm{N}_{2}$ adsorptiondesorption isotherm obtained for porous natural clay is shown in Figure 2. As shown in Figure 2, the desorption branch of this isotherm exhibited hysteresis and correspond to the Type IV isotherm. The existence of the hysteresis loop in the isotherm is due to the capillary condensation of $\mathrm{N}_{2}$ gas occurring in the mesopores and therefore, the

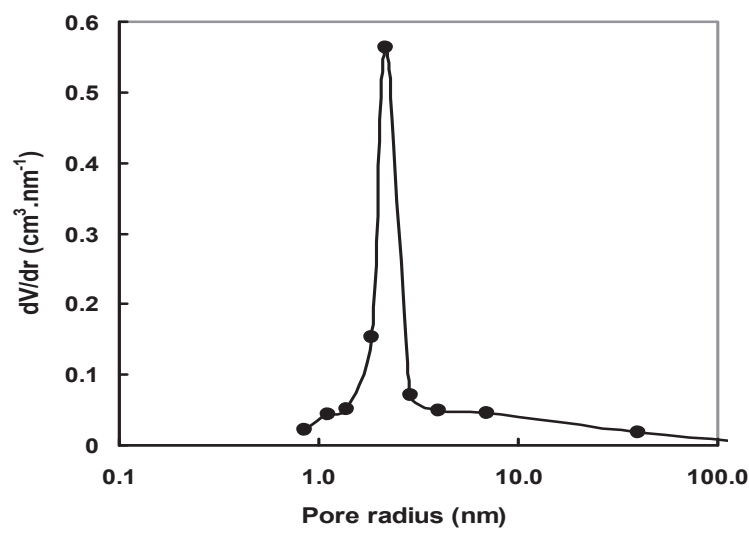

Fig. 2 Adsorption isotherms of clay tested with $\mathrm{N}_{2}$ at $77.35 \mathrm{~K}$. Type IV isotherm is considered as the characteristic feature of the mesoporous materials (Gregg, 1982). The sharp rise near P/Po $=0.4$ corresponds. The well-defined hysteresis loop between the adsorption and desorption branches can be classified as type H4 according to the IUPAC classification (Gregg, 1982). The shape of hysteresis loop indicates that the pores have ink-bottle type pores. Physical 
characteristics of the Yemen natural clay such as the values of BET surface area (SBET), total pore volume (VT), micropores volume (Vmic), mesopores volume (Vmes), macropores volume (Vmac), and average pore radius (rav) are listed in Table 1.

It is obvious from Table 1 that natural clay has high specific surface area $\left(82.3 \mathrm{~cm}^{2} \cdot \mathrm{g}^{-1}\right)$ and total pore volume $\left(0.109 \mathrm{~cm}^{3} \cdot \mathrm{g}^{-1}\right)$. The high surface area and total pore volume of the natural clay gained high adsorption capacity towards AR97.

Table 1 Surface characteristics of natural clay

\begin{tabular}{|l|l|}
\hline Total surface area $\left(\mathrm{S}_{\mathrm{BET}}\right)\left(\mathrm{m}^{2} / \mathrm{g}\right)$ & 82.34 \\
\hline Total pore volume $\left(\mathrm{V}_{\mathrm{T}}\right)\left(\mathrm{cm}^{3} / \mathrm{g}\right)$ & 0.109 \\
\hline Average pore radius $\left(\mathrm{r}_{\mathrm{av}}\right)(\AA)$ & 26.40 \\
\hline Micropores volume $\left(\mathrm{V}_{\mathrm{mic}}\right)\left(\mathrm{cm}^{3} / \mathrm{g}\right)$ & 0.012 \\
\hline Mesopores volume $\left(\mathrm{V}_{\mathrm{mes}}\right)\left(\mathrm{cm}^{3} / \mathrm{g}\right)$ & 0.096 \\
\hline Macropores volume $\left(\mathrm{V}_{\mathrm{mac}}\right)\left(\mathrm{cm}^{3} / \mathrm{g}\right)$ & 0.001 \\
\hline Solid-phase density $\left(\rho_{\mathrm{s}}\right)\left(\mathrm{g} / \mathrm{cm}^{3}\right)$ & 2.526 \\
\hline Particle density $\left(\rho_{\mathrm{p}}\right)\left(\mathrm{g} / \mathrm{cm}^{3}\right)$ & 1.859 \\
\hline Particle porosity $\left(\varepsilon_{\mathrm{p}}\right)$ & 0.264 \\
\hline
\end{tabular}

Table 2 Value of separation factor RL

\begin{tabular}{|r|c|}
\hline Value of & Types of isotherm \\
\hline $\mathrm{R}_{\mathrm{L}}>1$ & Unfavorable \\
\hline $\mathrm{R}_{\mathrm{L}}=1$ & Linear \\
\hline $0<\mathrm{R}_{\mathrm{L}}<1$ & Favorable \\
\hline $\mathrm{R}_{\mathrm{L}}=0$ & Irreversible \\
\hline
\end{tabular}

Pore size distribution is one of the most important parameters for any porous adsorbent because the size of pores must be larger than the adsorbate molecule volume to allow it to enter inside the adsorbent particle pores. Figure 3 shows pore size distribution (PSD) of natural clay calculated from $\mathrm{N}_{2}$ adsorption isotherm by applying the Barrett-Joyner-Hallenda (BJH) method using desorption branch of the isotherms (Barrett et al. 1951).

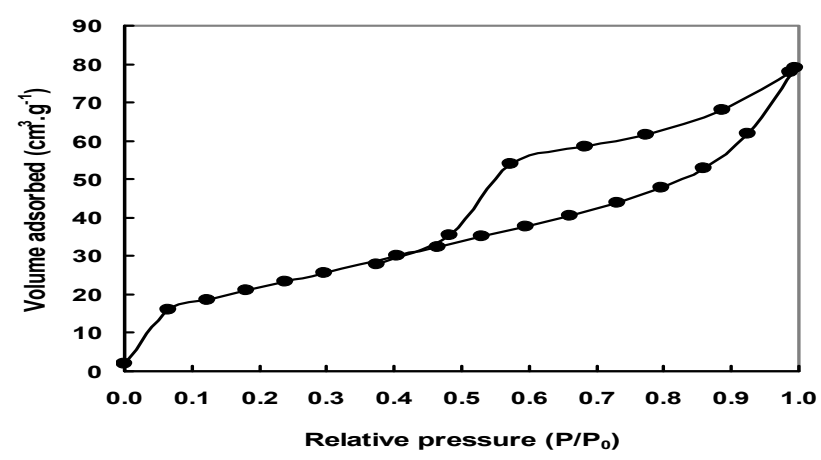

Fig. 3 Pore size distributions of clay determined by using BJH technique.

Their average pore size is $2.997 \mathrm{~nm}$ determined by $(\mathrm{BJH})$ method, which was in the mesopores range (pore size, 2-50 as illustrated in Figure 3, pores between 1.4 and $2.9 \mathrm{~nm}$ were dominant. Mineralogical analysis (XRD analysis) proved that clay is composed of montomorillonite and illite as clay minerals and quartz and gypsum as non-clay minerals.

\subsection{Adsorption Isotherms}

The adsorption isotherm indicates that the adsorption molecules distribute between the liquid phase and the solid phase when the adsorption process reaches an equilibrium state. Determining the distribution of AR97 between natural clay and the liquid phase when the system is in a state of equilibrium is important in establishing the capacity of the clay for AR97. Preliminary experiments showed that such equilibrium was established within $180 \mathrm{~min}$; however, all equilibrium experiments were allowed to run for $300 \mathrm{~min}$.

Plotting the amount of AR97 adsorbed at equilibrium, $q_{\mathrm{e}}$, against final concentration in the aqueous phase, Ce, at different temperatures and different particle size ranges gave a characteristic S-shaped curve as shown in Figures 4 and 5. From the shapes of the initial portions of the curves, the isotherms corresponding to the AR97 may be classified as S-shape (Giles classification) suggesting a low affinity of natural clay toward AR97 with strong competition from the solvent molecules for the available adsorption sites (Gilles et al. 1960). The S-shape isotherm suggests a cooperative adsorption that operates if adsorbate-adsorbate interaction is stronger than adsorbate-adsorbent interaction. In addition to these, the S-type isotherm is more indicative of physical adsorption (Yurdakoc et al. 2005). The same type of isotherm (S-shape) was obtained for the adsorption of AR97 onto activated carbon by (Gömez et al.1998). Similar results were reported by (Grant et al. 1998, El-Nahal and Safi, 2004 and El-Guendi et al. 2005).

Figure 4 shows that the experimental equilibrium adsorption capacity of AR97 onto clay decreases with increasing temperature, decreasing from $196.7\left(\mathrm{mg} . \mathrm{g}^{-1}\right)$ at $15{ }^{\circ} \mathrm{C}$ to $145.7\left(\mathrm{mg} \cdot \mathrm{g}^{-1}\right)$ at $65^{\circ} \mathrm{C}$ indicating that physical adsorption takes place. This decrease in adsorption capacity with the increase in temperature may be due to the enhancement of dye solubility and desorption step in the adsorption mechanism. It is also due to the weakening of adsorptive forces between the active sites on the clay and the dye species, and 
also between adjacent dye molecules on the solid phase (Tan, 2008).
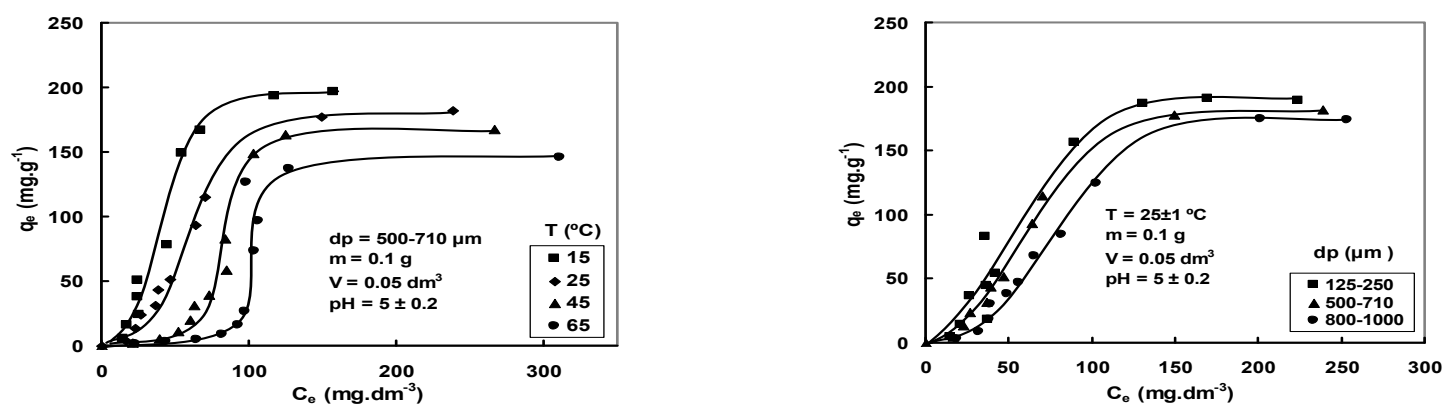

Fig. 4 Adsorption isotherms of AR97 onto clay at different Temperature Fig. 5 Adsorption isotherms of AR97 onto clay at different particle size ranges

Figure 5 shows that a decrease in clay particle size led to an increase in equilibrium adsorption capacity. The experimental equilibrium adsorption capacity of clay for AR97 increased from 174.3 (mg.g ${ }^{-1}$ ) to 189.1 (mg.g- ${ }^{1}$ ) with decreasing particle size range from 800 $1000 \mu \mathrm{m}$ to $125-250 \mu \mathrm{m}$. This behavior can be attributed to the inability of the large dye molecules to penetrate into the internal pore structure of clay. Apparently, breaking up large particle diameter to form smaller ones probably serves to open some tiny, sealed pores in the clay which become available for adsorption, thus slightly increasing the total specific surface area of a given mass of clay (AlDegs et al. 2000). The higher efficiency in removing AR97 observed in the case of smaller-sized fraction of clay can be attributed to the increase in the available surface area with the decrease in particle size, in which smaller diffusion distance expected over smaller particles and the ability of the large dye molecules to access most of the active sites in the internal pore structure of clay will increase. Several investigations have shown similar observation for clay minerals and other adsorbents (Wong, et al. 2008, Ponnusami et al. 2008).

\subsection{Analysis of adsorption isotherms}

The adsorption equilibrium data obtained for the AR97 onto natural clay were fitted into five different isotherm models to determine the most suitable model to represent the adsorption process. The isotherms used are the Langmuir isotherm, the Freundlich, the Temkin, the Redlich-Peterson and the Sips isotherms. In order to quantitatively compare the applicability of different models, the average relative error (ARE) was calculated using equations (2):

$A R E=\frac{1}{N}\left[\sum_{i=1}^{N}\left|\frac{q_{e, c a l}-q_{e, e x p}}{q_{e, \exp }}\right|\right]$

where $N$ is the number of data points, $q_{\text {exp }}$ and $q_{\text {cal }}\left(\mathrm{mg} \cdot \mathrm{g}^{-1}\right)$ are the experimental and the calculated values of the equilibrium adsorbate solid concentration in the solid phase, respectively. The values of ARE is used as measures of the fitting of the data to an isotherm equation, small values of ARE would indicate a perfect fit.

\subsubsection{Langmuir isotherm}

The Langmuir isotherm (Langmuir, 1918) is valid for monolayer adsorption on a homogenous adsorbent surface containing a finite number of identical site and no interaction between adsorbate molecules. The Langmuir expression is represented by the following equation.

$q_{e}=\frac{1+K_{L} C_{e}}{1+a_{L} C_{e}}$

Where qe is the solid phase equilibrium concentration $\left(\mathrm{mg} \cdot \mathrm{g}^{-1}\right), C_{\mathrm{e}}$ is the liquid phase equilibrium concentration $(\mathrm{mg} \cdot \mathrm{dm}-3), K_{\mathrm{L}}\left(\mathrm{dm} \mathrm{g}^{-1}\right)$ and $a_{\mathrm{L}}\left(\mathrm{dm}^{3} \cdot \mathrm{mg}^{-1}\right)$ are the Langmuir constants. This may be converted into a linear form which is convenient for plotting and determining the constants $K_{\mathrm{L}}$ and $a_{\mathrm{L}}$ :

$\frac{C_{e}}{q_{e}}=\frac{a_{L}}{K_{L}} C_{e}+\frac{1}{K_{L}}$ 
Linear plots of $\left(C_{\mathrm{e}} q_{\mathrm{e}}{ }^{-1}\right)$ versus $\left(C_{\mathrm{e}}\right)$ suggest the applicability of the Langmuir isotherm and demonstrate monolayer coverage of the adsorbate on the outer surface of the adsorbent (Panday et al. 1984). The essential characteristics of the Langmuir isotherm can be expressed in terms of a dimensionless equilibrium parameter $\left(R_{\mathrm{L}}\right)$ which is defined by:

$R_{L}=\frac{1}{\left(1+K_{L} C_{o}\right)}$

Where $R_{L}$ is a dimensionless constant separation factor, $\mathrm{C}_{\mathrm{o}}$ is the initial concentration of dye $\left(\mathrm{mg} . \mathrm{dm}^{-3}\right)$ and $\mathrm{K}_{\mathrm{L}}$ is the Langmuir adsorption constant $\left(\mathrm{dm}^{3} \cdot \mathrm{g}^{-1}\right)$ (Weber et al. 1974). The equilibrium parameter indicates the shape of the isotherm and whether the adsorption is favorable or not, as listed in Table 2. The values of $\mathrm{K}_{\mathrm{L}}$ and $\mathrm{a}_{\mathrm{L}}$ have been calculated for the different variables studied using Eqn. (4) and listed in Table 3. The values of the constant $\left(\mathrm{K}_{\mathrm{L}} / \mathrm{a}_{\mathrm{L}}\right)$ correspond to the maximum adsorption capacity ( $\left.\mathrm{q}_{\max }\right)$ of the clay for AR97 were determined.

Table 3 Estimated Langmuir parameters and Freundlich parameters for the adsorption of AR97 onto natural clay at different variables.

\begin{tabular}{|c|c|c|c|c|c|c|c|c|c|c|c|c|c|c|c|}
\hline \multirow{3}{*}{$\begin{array}{c}\begin{array}{l}\text { Adsorption } \\
\text { conditions }\end{array} \\
\mathbf{T}\left({ }^{\circ} \mathbf{C}\right) \\
\end{array}$} & \multicolumn{5}{|c|}{ Langmuir } & \multicolumn{10}{|c|}{ Freundlich } \\
\hline & & & & & & \multicolumn{3}{|c|}{ First section of plot } & \multicolumn{3}{|c|}{ Second section of plot } & \multicolumn{3}{|c|}{ Third section of plot } & \multirow[t]{2}{*}{ ARE } \\
\hline & $\mathbf{K}_{\mathbf{L}}$ & $\mathbf{a}_{\mathrm{L}}$ & $q_{m}$ & $\mathbf{R}_{\mathrm{L}}$ & ARE & $\mathbf{K}_{\mathbf{F}}$ & $\mathbf{n}$ & C.R. & $\mathbf{K}_{\mathbf{F}}$ & $\mathbf{n}$ & C.R. & $\mathbf{K}_{\mathbf{F}}$ & $\mathbf{n}$ & C.R. $\mathbf{R}^{1}$. & \\
\hline 25 & 19.84 & 0.106 & 188.7 & 0.234 & 6.877 & 0.017 & 0.474 & $0-66.0$ & 13.64 & 2.531 & $\begin{array}{l}66.0- \\
238.5\end{array}$ & --- & --- & --- & 0.144 \\
\hline 45 & 11.27 & 0.063 & 178.6 & 0.056 & 8.891 & 0.007 & 0.540 & $0-52.3$ & $2.9 \times 10^{-05}$ & 0.302 & $\begin{array}{l}52.3- \\
108.5\end{array}$ & 98.13 & 10.21 & $\begin{array}{l}108.5- \\
266.0\end{array}$ & 0.110 \\
\hline 65 & 7.930 & 0.052 & 153.9 & 0.015 & 1.358 & 0.029 & 0.820 & $0-78.2$ & $2.2 \times 10^{-18}$ & 0.103 & $\begin{array}{l}78.2- \\
110.0\end{array}$ & 79.03 & 9.32 & $\begin{array}{l}110.0- \\
311.0\end{array}$ & 0.146 \\
\hline \multicolumn{16}{|l|}{$\mathrm{dp}(\mu \mathrm{m})$} \\
\hline $125-250$ & 93.50 & 0.486 & 192.3 & 0.110 & 5.778 & 0.001 & 0.287 & $0-26.2$ & 0.605 & 0.817 & $\begin{array}{l}26.2- \\
98.0\end{array}$ & 64.46 & 4.84 & $\begin{array}{l}98.0- \\
224.0\end{array}$ & 0.261 \\
\hline $500-710$ & 19.84 & 0.106 & 188.7 & 0.234 & 6.877 & 0.017 & 0.474 & $0-66.0$ & 13.64 & 2.531 & $\begin{array}{l}66.0- \\
238.5\end{array}$ & --- & --- & --- & 0.144 \\
\hline $800-1000$ & 51.80 & 0.300 & 172.4 & 0.567 & 7.377 & 0.001 & 0.369 & $0-45.5$ & 0.118 & 0.666 & $\begin{array}{l}45.5- \\
104.1\end{array}$ & 20.07 & 2.51 & $\begin{array}{l}104.0- \\
253.7\end{array}$ & 0.102 \\
\hline
\end{tabular}

It is clear from Table 3 that temperature plays an interesting role in the adsorption of AR97. Increasing temperature from $15^{\circ} \mathrm{C}$ to $65^{\circ} \mathrm{C}$ led to a decrease in the maximum adsorption capacity from $204.1\left(\mathrm{mg} \cdot \mathrm{g}^{-1}\right)$ to $153.9\left(\mathrm{mg}^{\mathrm{g}} \mathrm{g}^{-1}\right)$ as shown in Table 3 . This demonstrates the exothermic nature of the process. Similar observation was reported for the adsorption of Acid Blue 193 onto modified sepiolite (Özcan et al. 2006). The data listed in Table 3 indicate also a decrease in the maximum adsorption capacity $\left(q_{\mathrm{m}}\right)$ with the increase in particle size range. Increasing particle size ranges from $125-250 \mu \mathrm{m}$ to $800-1000 \mu \mathrm{m}$ led to a decrease in the maximum adsorption capacity from $192.3\left(\mathrm{mg} \cdot \mathrm{g}^{-1}\right)$ to $172.4\left(\mathrm{mg} \cdot \mathrm{g}^{-1}\right)$. Comparing the results obtained in this study to that in literature, it was found that Yemen natural clay and activated carbon have the same shape of isotherm (S-shape), however the maximum adsorption capacity for Yemen natural clay was $204.1\left(\mathrm{mg} . \mathrm{g}^{-1}\right)$ compared to that $52.1\left(\mathrm{mg}^{\mathrm{g}} \mathrm{g}^{-1}\right.$ ) for activated carbon (Gömez et al. 2007). Values of $\mathrm{R}_{\mathrm{L}}$ for natural clay/AR97 system have been calculated and listed in Table 3. According to $\mathrm{R}_{\mathrm{L}}$ values in Table 3, the adsorption behavior of AR97 was favorable $\left(0<R_{L}<1\right)$.

\subsubsection{Freundlich Isotherm}

The Freundlich isotherm (Freundlich, 1906) is the first known relationship describing the adsorption equilibrium. This isotherm can be used for non-ideal adsorption on heterogeneous surfaces and derived by assuming an exponentially decaying adsorption site energy distribution. The heterogeneity arises from the presence of different functional groups on the surface, and the various adsorbentadsorbate interactions. The experimental equilibrium data for the adsorption of AR97 onto clay at different temperatures and particle size ranges have been analyzed using the Freundlich isotherm as given by equation (6).

$q_{e}=K_{F} C_{e}{ }^{1 / n}$

Where $q_{e}$ is the equilibrium solid-phase concentration $\left(\mathrm{mg} \cdot \mathrm{g}^{-1}\right), C_{\mathrm{e}}$ is the equilibrium liquid-phase concentration $\left(\mathrm{mgdm}^{-3}\right), K_{\mathrm{F}}$ is Freundlich constant $\left(\mathrm{mg} \cdot \mathrm{g}^{-1}\right) /\left(\mathrm{dm}^{\mathrm{f}} \cdot \mathrm{mg}^{-1}\right)^{\mathrm{n}}$ and $\mathrm{n}$ is the heterogeneity factor. The $K_{\mathrm{F}}$ value is related to the adsorption capacity; while $1 / \mathrm{n}$ value is related to the adsorption intensity. The magnitude of exponent (n) gives an indication of the favorability and capacity of the adsorbent/adsorbate system. Values of (n) greater than 1 represent favorable adsorption according to Treybal (Treybal, R. E, 1985). 
Equation 6 may be linearized via a logarithmic plot which enables the exponent $(\mathrm{n})$ and the constant $\left(K_{\mathrm{F}}\right)$ to be determined:

$\log \left(q_{e}\right)=\log \left(K_{F}\right)+(1 / n) \log \left(C_{e}\right)$

However, a Log-Log plot of the equilibrium data for the adsorption of AR97 onto clay did not quite give straight lines, as required by the Freundlich equation, when only one line was used to represent the whole concentration range of experimental data but showed some curvature. However, if the whole concentration range is divided into sections of plot, i.e. first section of plot, second section of plot third section of plot, good fits to the experimental data can be observed. This method was used by different researchers as reported in the literature whereby it has been divided up into sections (El-Geundi et al. 2005, Wong et al. 2003, Nassar et al. 2002). For this reason the Freundlich constants had to be changed, in terms of equation (8), to obtain a good representation of the data over the entire concentration range. A general equation for the entire concentration range may be expressed as:

$q_{e}=K_{F, i} C_{e}^{1 / n i}$

Figures 6 shows the fit of the Freundlich isotherm model to the experimental data obtained at different temperatures. Similar behavior was obtained at different particle size ranges as shown in Figure 7. The Freundlich parameters $\left(K_{\mathrm{F}}\right.$ and $\left.\mathrm{n}\right)$ have been calculated using the least-squares method applied to the straight lines shown in Figures 6 and 7 and are listed in Table 3 together with the appropriate concentration ranges and the error functions values obtained. According to the results, the values of $\mathrm{n}$ are greater than unity indicating that the adsorption of dye onto clay is favorable. This is in great agreement with the findings regarding to $R_{\mathrm{L}}$ values.

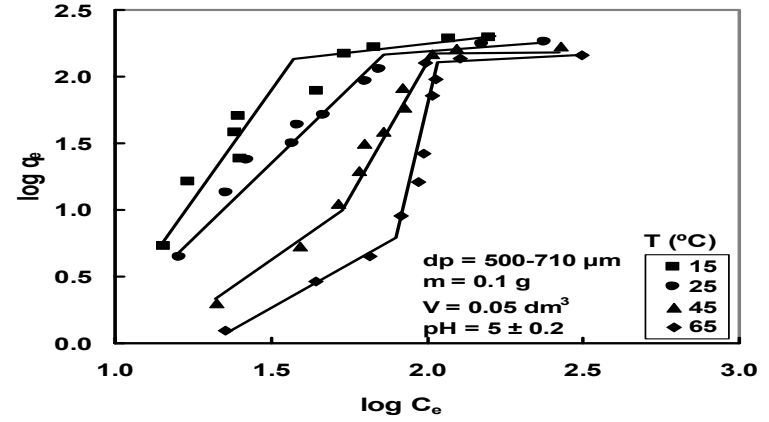

Fig. 6 Freundlich plots for the adsorption of AR97 onto clay particle size ranges.

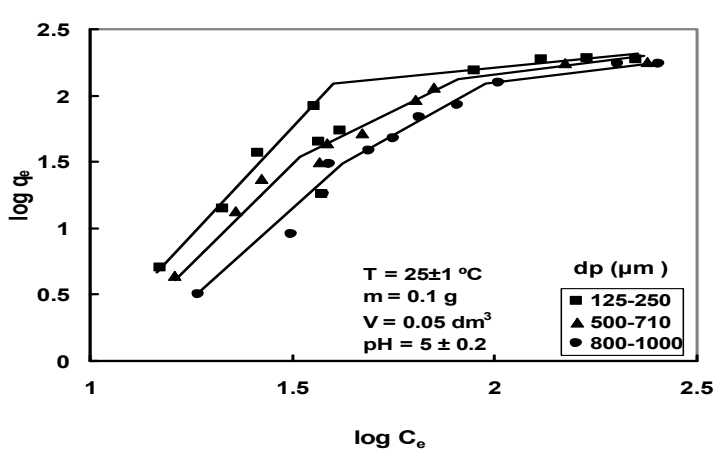

Fig. 7 Freundlich plots for the adsorption of AR97 onto clay at different at different temperatures

\subsubsection{Temkin Isotherm}

The Temkin isotherm (Temkin, 1941) has been used in the following form:

$q_{e}=\frac{R T}{b_{T}}\left(\ln \left(A_{T} C_{e}\right)\right)$

Equation (9) can be expressed in its linear form as:

$q_{e}=B_{T} \ln \left(A_{T}\right)+B_{T} \ln \left(C_{e}\right)$

Where, $B_{T}=\frac{R T}{b_{T}}$

And $\mathrm{T}$ is the absolute temperature $(\mathrm{K}), \mathrm{R}$ is the universal gas constant $\left(\mathrm{J} \cdot \mathrm{g}-\mathrm{mol}^{-1} \cdot \mathrm{K}^{-1}\right), \mathrm{A}_{\mathrm{T}}$ is the equilibrium binding constant corresponding to the maximum binding energy $\left(\mathrm{dm}^{3} \cdot \mathrm{mg}^{-1}\right), \mathrm{b}_{\mathrm{T}}$ is Temkin isotherm constant $\left(\mathrm{J} . \mathrm{g}-\mathrm{mol}^{-1}\right)$ and the constant $\mathrm{B}_{\mathrm{T}}$ is related to the heat of adsorption (dimensionless) (Bulut, et al. 2008). According to equation (10), a plot of $\left(q_{\mathrm{e}}\right)$ against ln $\left(C_{\mathrm{e}}\right)$ enables the determination of the isotherm constants $\left(\mathrm{A}_{\mathrm{T}}\right.$ and $\left.\mathrm{B}_{\mathrm{T}}\right)$. The linearized Temkin adsorption isotherms for AR97 onto clay at different temperatures and particle size ranges are presented in Figures 8 and 9. The estimated Temkin isotherm constants values $\left(A_{T}\right.$ and $\left.B_{T}\right)$ calculated from the slopes and the intercepts of the straight lines of Figures $\mathbf{8}$ and $\mathbf{9}$ are listed in Table 4. Table 4 estimated Langmuir parameters and Freundlich parameters for the adsorption of AR97 onto natural clay at different variables. As shown in the figures, high deviation from the linearity occurred for the temperatures and pracle size ranges studied. This indicates that the equilibrium adsorption behavior of the AR97 onto clay does not follow Temkin isotherm model. Fig. 8 also show that deviation from linearity increased by increasing temperature which indicates a nonliner decrease in the heat of adsortopn with coverag at high temperature for the adsorption of AR97 onto clay. Similar results have been reported (Mane, et al. 2007). 


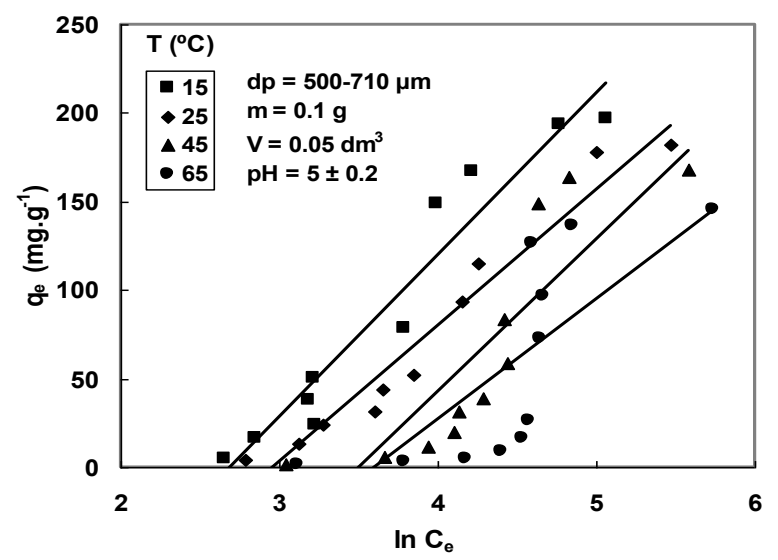

Fig. 8 Temkin plots for the adsorption of AR97 onto clay at different temperatures.

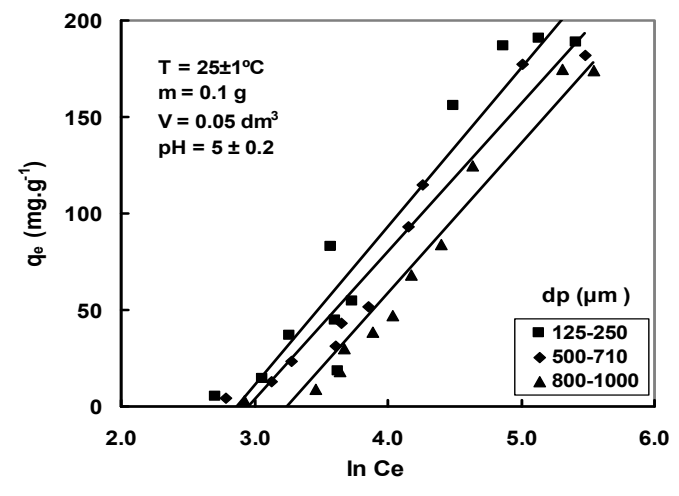

Fig. 9. Temkin plots for the adsorption of AR97 onto clay at different particle size ranges

\subsubsection{Redlich-Peterson Isotherm}

The Redlich-Peterson isotherm contains three parameters and involves the features of both the Langmuir and the Freundlich isotherms (Redlich, 1959). It can be described as follows:

$q_{e}=\frac{\left(K_{R P} \cdot C_{e}\right)}{\left(1+a_{R P} \cdot C_{e}^{\beta}\right)}$

Where $K_{\mathrm{RP}}$ is the modified Langmuir constant $\left(\mathrm{dm}^{3} / \mathrm{g}\right), \mathrm{a}_{\mathrm{RP}}\left(\mathrm{dm}^{3} / \mathrm{mg}\right)$ and $\beta$ are constant. $\beta \leq 1$.

The isotherm parameters in equation (12) is calculated by optimization routine to minimize the ARE between experimental data and Redlich- Peterson model across the concentration range studied using the solver add-in with Microsoft's excel spreadsheet, (Ho et al. 2002, Ho, 2006), and listed with the values of ARE in Table 4.

\subsubsection{Sips Isotherm}

Sips isotherm (Sips, 1948) is a combination of the Langmuir and Freundlich isotherm type models and expected to describe heterogeneous surfaces much better. At low adsorbate concentrations it effectively reduces to a Freundlich isotherm and thus does not obey Henry's law, while at high adsorbate concentrations it predicts a monolayer adsorption capacity characteristic of the Langmuir isotherm (Günay et al. 2007). The model can be written as:

$q_{e}=\frac{q_{m} a_{s} c_{e}^{n_{s}}}{\left(1+a_{s} c_{e}^{n_{s}}\right)}$

Where $q_{\mathrm{ms}}$ is the Sips maximum adsorption capacity $\left(\mathrm{mg} \cdot \mathrm{g}^{-1}\right), a_{s}$ is Sips constant $\left(\mathrm{dm}^{3} \cdot \mathrm{mg}^{-1}\right)^{\mathrm{ns}}$ and $\left(\mathrm{n}_{\mathrm{S}}\right)$ is the heterogeneity factor. Sips constants were evaluated by the same method used for Redlich-Peterson isotherm. Table 4 shows the values of maximum adsorption capacity $\left(q_{\mathrm{ms}}\right)$ and Sips constants for the adsorption of AR97 onto clay at different temperatures and particle size ranges. As shown in Table 4, maximum adsorption capacity decreases with increasing temperature and particle size ranges.

\subsection{Simulation Results and Correlations}

To optimize the design of an adsorption system for the adsorption of adsorbate, it is important to establish the most appropriate correlation for the equilibrium curves. Various isotherm equations like those of Langmuir, Freundlich, Temkin, Redlich-Peterson and Sips have been used to describe the equilibrium characteristics of adsorption of AR97 onto clay. Using the appropriate constants of the Langmuir, the Freundlich, the Temkin, the Redlich-Peterson, and the Sips equations, the theoretical isotherm curves were predicted for the adsorption of AR97 and clay using known values of $\left(C_{\mathbf{e}}\right)$. 
Table4 Estimated Temkin parameters, Redlich-Peterson model parameters and Sips model parameters for the adsorption of AR97 onto natural clay at different variables.

\begin{tabular}{|c|c|c|c|c|c|c|c|c|c|c|c|}
\hline \multirow{2}{*}{$\begin{array}{c}\begin{array}{c}\text { Adsorption } \\
\text { Conditions }\end{array} \\
\mathbf{T}\left({ }^{\circ} \mathrm{C}\right)\end{array}$} & \multicolumn{3}{|l|}{ Temkin } & \multicolumn{4}{|c|}{ Redlich-Peterson } & \multicolumn{4}{|c|}{ ips } \\
\hline & $\mathbf{B}_{\mathrm{T}}$ & $\overline{\mathbf{A}_{\mathrm{T}}}$ & ARE & $\mathrm{K}_{\mathrm{RP}}$ & $\mathbf{a}_{\mathrm{RP}}$ & $\boldsymbol{\beta}$ & ARE & $\mathbf{q}_{\mathrm{m}}$ & $\mathbf{a}_{\mathrm{s}}$ & $\mathbf{n}_{\mathbf{S}}$ & ARE \\
\hline 15 & 91.67 & 0.068 & 0.317 & 2.577 & 0.005 & 0.999 & 0.871 & 204.97 & $1.76 \mathrm{E}-5$ & 0.345 & 0.206 \\
\hline 25 & 76.68 & 0.052 & 0.549 & 1.585 & 0.004 & 0.999 & 0.819 & 188.93 & $9.64 \mathrm{E}-6$ & 0.358 & 0.106 \\
\hline 45 & 86.08 & 0.030 & 2.577 & 0.973 & 0.001 & 0.999 & 1.896 & 174.93 & $5.36 \mathrm{E}-14$ & 0.146 & 0.342 \\
\hline 65 & 67.61 & 0.027 & 4.383 & 0.708 & 0.001 & 0.999 & 3.511 & 146.61 & $6.90 \mathrm{E}-23$ & 0.090 & 0.593 \\
\hline \multicolumn{12}{|l|}{$\mathrm{dp}(\boldsymbol{\mu m})$} \\
\hline $125-250$ & 82.01 & 0.057 & 0.685 & 1.875 & 0.004 & 0.999 & 0.869 & 200.86 & $2.59 \mathrm{E}-5$ & 0.383 & 0.276 \\
\hline $500-710$ & 76.68 & 0.052 & 0.549 & 1.585 & 0.004 & 0.999 & 0.819 & 188.93 & $9.64 \mathrm{E}-6$ & 0.358 & 0.106 \\
\hline $800-1000$ & 77.89 & 0.039 & 0.1027 & 1.069 & 0.002 & 0.999 & 0.894 & 185.77 & $6.74 \mathrm{E}-6$ & 0.370 & 0.105 \\
\hline
\end{tabular}

In order to confirm the fit model for the adsorption system, it is necessary to analyze the data using error function ARE. The traditional approach of determining isotherm parameters is based on the linearized form of isotherm equation by best fitting the linearized isotherm equation to the experimental data. However, the correlation coefficient $\left(\mathrm{R}^{2}\right)$ generated from this method has the drawback that it may not provide the best isotherm constants for correlating the original (non-linearized) isotherm equation with experimental data points (Cheung et al. 2009). Because the use of $\left(\mathrm{R}^{2}\right)$ is limited to solving linear forms of isotherm equations which measure the difference between experimental and theoretical data in linear plots only, but not the errors in isotherm curves (Crini et al. 2008). For that reason, the error functions were used to confirm the best model that gave the best fit to the experimental data. These values are a measure of the fitting of the data to an isotherm equation, a small of error function would indicate a perfect fit. Figures $\mathbf{1 0}$ and $\mathbf{1 1}$ shows the fit of the isotherm models to the experimental data for the adsorption of RA97 onto Yemen natural clay at $\mathrm{T}=45^{\circ} \mathrm{C}$ and $\mathrm{dp}$ $=800-1000 \mu \mathrm{m}$, respectively. It is clear from the Figures that the Freundlich and Sips isotherms gave the best fit for the experimental data among the five isotherms used. The in ability of Langmuir model to simulate the experimental data can be attributed to the fact that Langmuir model does not take into account adsorbate-adsorbate interactions which were active in this adsorption process (Gömez et al. 2007). According to the data in Tables 2 and 3 it is clear that the values of the error functions for the Freundlich isotherm was found to be smallest at different temperatures and particle size ranges, whereas at temperatures $15,25^{\circ} \mathrm{C}$ with particle size ranges 500 $710 \mu \mathrm{m}$ the Sips isotherm was found to be the best isotherm to fit the experimental data according to the smallest values of the ARE and the graphical representation.

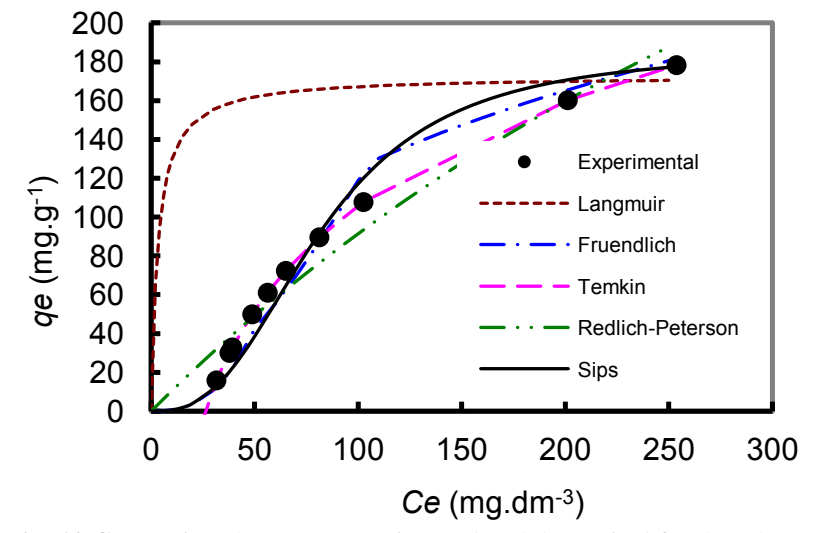

Fig. 10 Comparison between experimental and theoretical for the adsorption of AR97 onto clay at $\mathrm{T}=45^{\circ} \mathrm{C}$.

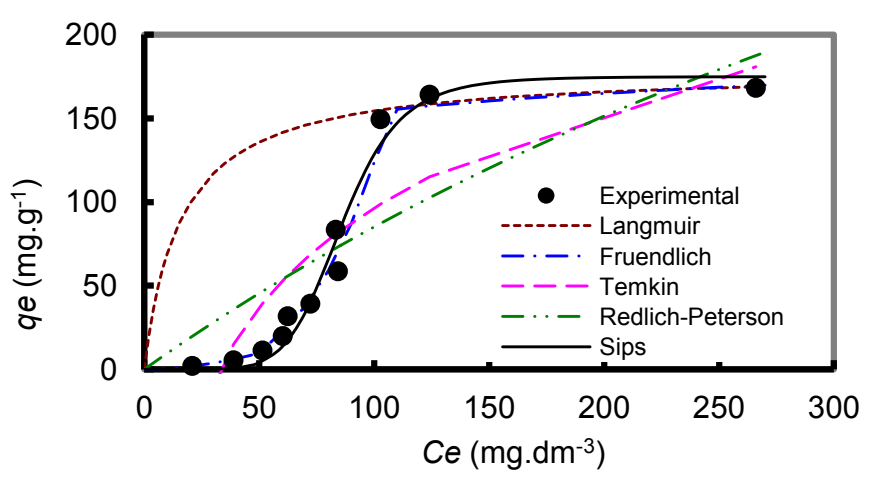

Fig. 11 Comparison between experimental and theoretical for adsorption of AR97 on isotherms clay, 800-1000 $\mu \mathrm{m}$

\subsection{Thermodynamic study}

The thermodynamic parameters that must be considered to determine the process are changes in standard enthalpy $\left(\Delta \mathrm{H}^{\circ}\right)$, standard entropy $\left(\Delta \mathrm{S}^{\circ}\right)$ and standard Gibbs free energy $\left(\Delta \mathrm{G}^{\circ}\right)$ due to transfer of unit mole of solute from solution onto the solid-liquid interface. The Gibbs free energy change of adsorption is defined as: 
$\Delta G^{o}=R T \ln \left(K_{L}\right)$

Where $\mathrm{K}_{\mathrm{L}}$ is Langmuir equilibrium constant $\left(\mathrm{dm} 3 \cdot \mathrm{g}^{-1}\right),(\mathrm{R})$ is the universal gas constant $\left(8.314 \mathrm{~J} \cdot \mathrm{g}-\mathrm{mol}^{-1} \cdot \mathrm{K}^{-1}\right)$ and $(\mathrm{T})$ is the absolute temperature $(\mathrm{K})$.

The values of $\left(\Delta \mathrm{H}^{\circ}\right)$ and $\left(\Delta \mathrm{S}^{\circ}\right)$ is computed using Van't Hoff equation:

$\log \left(K_{L}\right)=\frac{1}{2.303 R}\left(\Delta S^{o}-\frac{\Delta H^{o}}{T}\right)$

A plot of $\left(\log K_{L}\right)$ versus $(1 / \mathrm{T})$ should produce straight line with slope equals to $-\Delta \mathrm{H}^{\mathrm{o}} / \mathrm{RT}$ and intercept equals to $\Delta \mathrm{S} / \mathrm{R}$ (Cheung $e$ t al. 2001). Figure 12 shows linear relation between $\left(\log K_{L}\right)$ and $(1 / T)$ with very high correlation coefficient $\left(R^{2}>0.99\right)$. The values of $\left(\Delta \mathrm{H}^{\circ}\right)$ and $\left(\Delta \mathrm{S}^{\circ}\right)$ are calculated from the slope and the intercepts of straight line in Figure 12 and listed in Table 5. The values of standard Gibbs free energy $\left(\Delta \mathrm{G}^{\mathrm{o}}\right)$ are calculated using equation 14 and also listed in Table 5. The standard enthalpy $\left(\Delta \mathrm{H}^{\circ}\right)$ and entropy $\left(\Delta \mathrm{S}^{\circ}\right)$ changes of adsorption of AR97 onto clay determined from equation (15) were found to be $-20.5\left(\mathrm{~kJ} . \mathrm{g}-\mathrm{mol}^{-1}\right)$ and -43.6 $\left(\mathrm{J} . \mathrm{g}-\mathrm{mol}^{-1} \cdot \mathrm{K}^{-1}\right)$. Typically the magnitude of $\left(\Delta \mathrm{H}^{\circ}\right)$ for physical adsorption ranges from 4 to $40\left(\mathrm{~kJ} . \mathrm{g}-\mathrm{mol}^{-1}\right)$, compared to that of chemical adsorption ranging from 40 to $800\left(\mathrm{~kJ} . g-\mathrm{mol}^{-1}\right)$ (Cheung et al. 2001). The negative value of $\left(\Delta \mathrm{H}^{\circ}\right)$ for $\mathrm{AR} 97 / \mathrm{clay}$ system indicates the exothermic nature of the process. As the temperature increases, the mobility of dye molecules increases causing the molecules to escape from the solid phase to the liquid phase. Therefore, the amount of dye that can be adsorbed will decrease. The values of standard Gibbs energy change $\left(\Delta G^{o}\right)$ in all the cases are indicative of the spontaneous nature of the interaction without requiring large activation energies of adsorption and no energy input from outside of the system is required. The results in Table (5) show that the value of $\left(\Delta \mathrm{G}^{\circ}\right)$ increases with an increase in temperature, indicating lower temperature favored the adsorption. Generally, the change in free energy for physisorption is between -20 and $0\left(\mathrm{~kJ} \cdot \mathrm{g}-\mathrm{mol}^{-1}\right)$, but chemisorption (Crini, 2008) is in a range of -400 to $-80\left(\mathrm{~kJ} \cdot \mathrm{g}-\mathrm{mol}^{-1}\right)$.

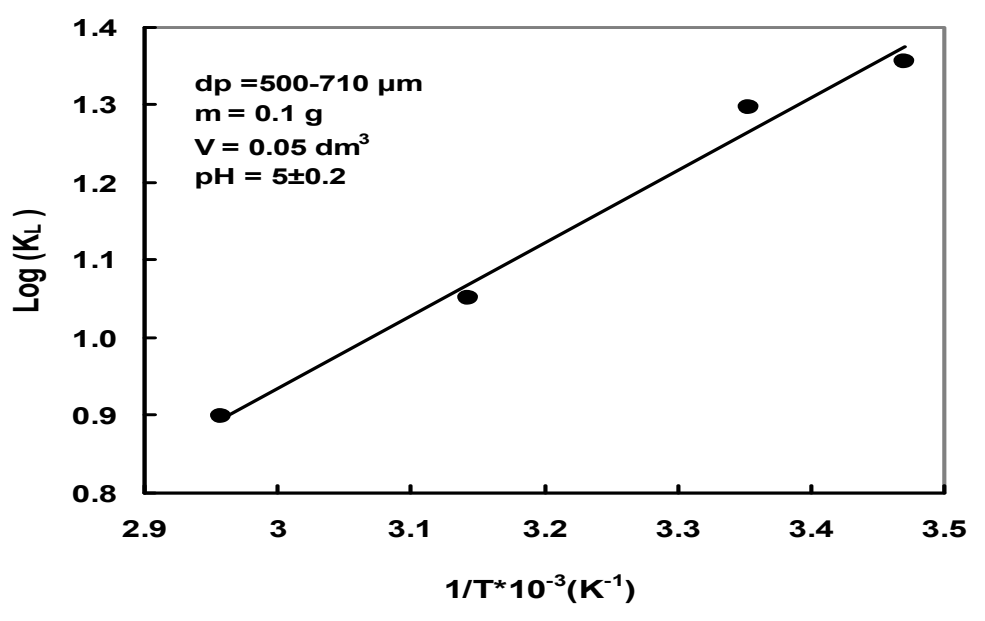

Table 5 Thermodynamic Parameters for the dsorption of

\begin{tabular}{|c|c|c|c|c|}
\hline $\mathbf{T}(\mathbf{K})$ & $\begin{array}{l}\Delta G^{0}(\mathrm{~kJ} . \mathrm{g}- \\
\left.\mathrm{mol}^{-1}\right)\end{array}$ & $\begin{array}{l}\Delta \mathbf{H}^{\mathbf{o}}(\mathrm{kJ} . \\
\left.\mathrm{g}-\mathrm{mol}^{-1}\right)\end{array}$ & $\begin{array}{l}\mathbf{\Delta S ^ { 0 }}(\mathbf{J} . \\
\mathbf{g m o l}^{-1} \cdot \mathbf{K}^{-}\end{array}$ & $\mathbf{R}^{2}$ \\
\hline $\begin{array}{c}288.15 \\
298.15 \\
318.15 \\
338.15\end{array}$ & $\begin{array}{l}-7.8 \\
-7.4 \\
-6.4 \\
-5.8\end{array}$ & -20.5 & -43.6 & 0.99 \\
\hline
\end{tabular}

Fig. 12 linear relation between $\left(\log K_{L}\right)$ and $(1 / \mathrm{T})$ for the Adsorption of AR97 onto Clay.

\section{Conclusions}

The equilibrium adsorption of AR97 onto Yemen natural clay at different temperatures and particle size ranges has been studied. Experimental data were mathematically modeled using Langmuir, Freundlich, Temkin, Redlich-Peterson, and Sips isotherm models. Thermodynamic parameters such as standard enthalpy $\left(\Delta \mathrm{H}^{\circ}\right)$, standard entropy $\left(\Delta \mathrm{S}^{\circ}\right)$ and standard Gibbs free energy $\left(\Delta \mathrm{G}^{\circ}\right)$ have been evaluated. Adsorption capacity increases with decreasing particle size range indicating that the dye molecules may not completely penetrate the particle or partly that the dye molecules preferentially adsorb near the external surface of the particle. Thus it can be concluded that smaller clay particles are needed for such adsorption processes. As the temperature increases, the adsorption capacity of AR97 onto clay decreases. The decrease in adsorption capacity with the increase in temperature exhibits the role of temperature in enhancing the dye solubility and desorption step during the adsorption processes. Therefore, one conclusion which can be drawn is that the adsorption process of AR97 onto clay is exothermic process, a fact proved by the negative value of $\left(\Delta \mathrm{H}^{\circ}\right)$. Among the five isotherm models applied, Freundlich and Sips models is found to best fit the experimental data as indicated from the low value of the average percent deviation (ARE). This would indicate the heterogeneity of the adsorbent surface and the significant role of the adsorbateadsorbate interactions. The values of thermodynamic parameters indicated that the process is spontaneous and exothermic. In 
laboratory-scale studies, Yemen natural clay proved potentially good adsorbent and low-cost adsorbent for removing azo dye from aqueous solutions and can be used as an alternative of the high cost commercial activated carbon.

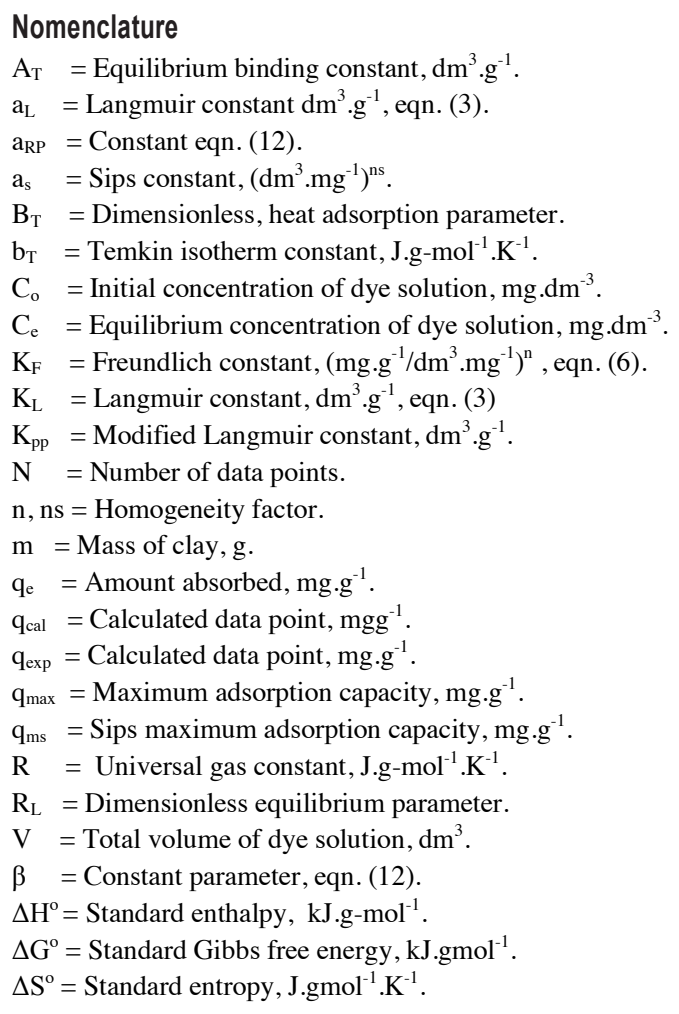

\section{References}

Ahmad, A. L., and B. H. Hameed "Adsorption of Basic Dye Using Activated Carbon Prepared from Oil Palm Shell: Batch and Fixed Bed Studies", Desalination, 255, 13-28, (2008).

Al-Degs, Y., Khraisheh, M. A. M., Allen, J. S., and M. N. Ahmad "Effect of Carbon Surface Chemistry on the Removal of Reactive Dyes from Textile Effluent”, Water Res., 34, 927-935, (2000).

Banat, I. M., Nigam, P.; Singh, D.; and R. Marchant "Microbial Decolorization of Textile-Dye-Containing Effluents: a Review. Biores", Technol. 58, 217-227, (1996).

Barrett, E. P., Joyner, L. G.,and P. P. Halenda "The Determination of Pore Volume and Area Distributions in Porous Substances. I. Computations from Nitrogen Isotherms", J. Am. Chem. Soc., 73, 373-380 (1951)

Baughman, G. L., and E. J. Weber "Transformation of Dyes and Related Compounds in Anoxic Sediment: Kinetics and Products", Environ. Sci. Technol., 28, 267-276 ( 1994).

Bhattacharyya, K. G., and S. S. Gupta "Adsorption of a Few Heavy Metals on Natural and Modified Kaolinite and Montmorillonite: A Review", Advances in Colloid and Interface Sci., 140,114-131 (2008).

Branauer, S., and Emmett, P.H., and E. Teller "Adsorption of Gases in Multimolecular Layers", J. Am. Chem. Soc., 60, 309-319 (1938).

Bulut, E.; Özacar, M.; and İ. A Şengil . "Equilibrium and Kinetic Data and Process Design for Adsorption of Congo Red onto Bentonite", J. Hazard. Mater., 154, 613-622 (2008).

Carliell, C. M., Barclay, S. J., Naidoo, N., Buckley, C.A., and D.A . Mulholland Senior, E. "Microbial Depolarization of a reactive azo dye under anaerobic conditions", Water S.A., 2, 61-69 (1995).

Chan, L. S., Cheung, W. H., Allen, S. J., and G. McKay “Separation of acid-Dyes Mixture by Bamboo Derived Active Carbon”, Sep. Purify. Technol, 67, 166$172,(2009)$.

Cheung, C. W., Porter; J. F., and G. McKay "Sorption Kinetic Analysis for the Removal of Cadmium Ions from Effluents Using Bone Char", Water Res., 35, $605-612,(2001)$.

Cheung, W. H., Szeto, Y. S.,and G. McKay “Enhancing the Adsorption Capacities of Acid Dyes by Chitosan Nano Particles”, Bioresour. Technol., 100, 1143$1148,(2009)$

Crini, G., and P. Badot "Application of Chitosan, a Natural Aminopolysaccharide, for Dye Removal from Aqueous Solutions by Adsorption Processes Using Batch Studies: A Review of Recent Literature", Prog. Polym. Sci., 33, 399-447 (2008).

Crini, G., Gimbert, F., Robert, C., Martel, B., Adam, O., Morin-Crini, N., Giorgi, F.D., and P. Badot "The Removal of Basic Blue 3 from Aqueous Solutions by Chitosan-Based Adsorbent: Batch Studies", J. Hazar. Mater., 153,96-106 (2008).

Dögan, M., Hamdi, M.; Karaoğlu K.; and M. Alkan "Adsorption Kinetics of Maxilon Yellow 4GL and Maxilon Red GRL Dyes on Kaolinite", J. Hazard Mater 165 1142-1152 (2009).

El Nemr A.; Abdelwahab, O., El-Sikaily, A., and A. Khaled "Removal of Direct Blue-86 from Aqueous Solution by New Activated Carbon Developed from Orange Peel", J. Hazard. Mater., 161, 102-110, (2009).

El Qada, E. N., Allen, J. S., and G. M. Walker "Kinetic Modeling of the Adsorption of Basic Dyes onto Steam-Activated Bituminous Coal", Ind. Eng. Chem. Res., 46, 4764-4771, (2007).

El-Geundi, M. S. "Adsorption Equilibria of Basic Dyestuffs onto Maize Cob", Adsorption Sci.\& Technol., 7, 114-123, (1990). 
El-Geundi, M. S., Farrag, T. E., and H. M. Abed El-Ghany "Adsorption Equilibrium of Herbicide (Pendimethalin) onto Natural Clay", Adsorpt. Sci. Technol., 23, 437-453(2005)

El-Nahhal, Y. Z., and J. M. Safi "Adsorption of Phenanthrene on Organoclays from Distilled and Saline Water",. J. Colloid Interface Sci., 269, 265-269 (2004).

Freundlich, H. M. F. "Over the Adsorption in Solution", J. Phys. Chem., 57, 385-471 (1906).

Gad, H. M. H., and A. A. El-Sayed. "Activated Carbon from Agricultural By-Products for the Removal of Rhodamine-B from Aqueous Solution", J. Hazard. Mater., 168, 1070-1081, (2009).

Gilles, C. H., Macewan, T. H., Nakhwa, S. N., and D. A. Smith "System of Classification of Solution Adsorption Isotherms, and its Use in Diagnosis of Adsorption Mechanisms", J. Chem. Soc., 4, 3973-3993, (1960).

Gömez, V., Larrechi, M. S., and M. P. Callao "Kinetic and Adsorption Study of Acid Dye Removal Using Activated Carbon", Chemosphere, 69, 11511158(2007).

Grant, P. G., Lemke, S. L., Dwyer, M. R., Timothy D., and T. d. Phillips "Modified Langmuir Equation for S-Shaped and Multisite Isotherm Plots", Langmuir, 14, 4292-4299(1998).

Gregg, S. J., and K. S. W. Sing, "Adsorption Surface Area and Porosity", $2^{\text {nd }}$ ed., Academic Press, London, U.K. 1982.

Günay, A., Arslankaya, E., and E. Tosun "Lead Removal from Aqueous Solution by Natural and Pretreated Clinoptilolite: Adsorption Equilibrium and Kinetics", J. Hazard. Mater, 146, 362-371, (2007).

Ho, Y. S. "Second-Order Kinetic Model for the Sorption of Cadmium onto Tree Fern: A Comparison of Linear and Non-Linear Methods", Water Research, 40, 119-125, ((2006).

Ho, Y. S., Porter, J. F., and McKay, G. "Equilibrium Isotherm Studies for the Sorption of Divalent Metal Ions onto Peat: Copper, Nickel and Lead Single Component Systems", Water, Air, and Soil Pollution, 141, 1-4, (2002).

Langmuir, I. "The Constitution and Fundamental Properties of Solids and Liquids", J. Am. Chem. Soc., 38, 2221-2295, (1916).

Mane, V. S., Mall, I. D., and Srivastava, V. C. "Kinetic and Equilibrium Isotherm Studies for the Adsorptive Removal of Brilliant Green Dye from Aqueous Solution by Rice Husk Ash", J. Environ. Manage. 84, 390-400, (2007).

Nassar, M. M., Daifullah, A. A., Magdy, Y. H., and E. E. Ebrahiem "Uptake of Cationic Dyes by Cement Kilen Dust: Sorption Mechanism and Equilibrium Isotherm", Adsorpt. Sci. Technol., 20 , 657.668,(2002).

Özcan, A., Öncü, E. M., and A. S. Özcan "Adsorption of Acid Blue 193 from Aqueous Solutions onto DEDMA-sepiolite", J. Hazard. Mater, 129, 244-252, (2006)

Panday, K .K., Parasad, G., and V. N. Singh "Removal of Cr (VI) from Aqueous Solutions by Adsorption on Fly Ash-Wollastonite", J. Chem. Technol. Biotechnol., 34A, 367-374, (1984).

Ponnusami, V., Vikram, S., and S. N. Srivastava "Guava (Psidium guajava) Leaf Powder: Novel Adsorbent for Removal of Methylene Blue from Aqueous Solutions", J. Hazard. Mater, 152, 276-286, (2008).

Ramakrishna, K. R., Viraraghavan, T., and A. Andreadakis "Dye Removal Using Low Cost Adsorbents", Water Sci. Technol., 36, 189-196, (1997).

Rao, P. H., He, M. "Adsorption of Anionic and Nonionic Surfactant Mixtures from Synthetic Detergents on Soils", Chemosphere, 63, 1214-1221, (2006).

Redlich, O., and D. L. Peterson "A Useful Adsorption Isotherm", J.Phys. Chem., 63, 1024-1024, (1959).

Robinson, T., Chandran, B., and P. Nigam "Removal of Dyes from a Synthetic Textile Dye Effluent by Biosorption on Apple Pomace and Wheat Straw", Water Res., 36, 2824-2830, (2002).

Robinson, T., McMullan, G., Marchant, R., and P. Nigam "Remediation of Dyes in Textile Effluent: A Critical Review on Current Treatment Technologies with a Proposed Alternative", Biores. Technol., 77, 247-255, (2001).

Sips, R. "Combined form of Langmuir and Freundlich Equations", J. Chem. Phys., 16, 490-495, (1948).

Temkin, M. I. "Adsorption Equilibrium and the Kinetics of Processes on Nonhomogeneous Surfaces and in the Interaction between Adsorbed Molecules", Zh. Fiz. Chim., 15, 296-332, (1941).

Treybal, R. E. "Mass Transfer Operation", $3^{\text {rd }}$ ed., McGraw-Hill Book Company, New York, U.S., 1985.

Vandevivere, P. C., Bianchi R., and Verstraete, W. "Treatment and Reuse of Wastewater from the Textile Wet-Processing Industry: Review of Emerging Technologies", J. Chem. Technol. Biotechnol., 72, 289-302, (1998).

Weber, T. W., and R. K. Chakravorti "Pore and solid Diffusion Models for Fixed Bed Adsorbers", Inst. of Chem. Eng. J., 20, 228-, (1974).

Wong, Y. C., Szeto, Y. S., Cheung, W. H., and G. McKay "Effect of Temperature, Particle Size and Percentage Deacetylation on the Adsorption of Acid Dyes on Chitosan", Adsorption, 14, 11-20, (2008).

Wong, Y. C., Szeto, Y. S., Cheung, W. H., and G. McKay "Equilibrium Studies for Acid Dye Adsorption onto Chitosan", Langmuir, 19, 7888-7902, (2003).

Yener, J., Kopac, T., Dogu, G., and T. Dogu "Dynamic Analysis of Sorption of Methylene Blue Dye on Granular and Powdered Activated Carbon", Chem. Eng. J., 144, 400-406, (2008).

Yurdakoç, M., Yolda s s Seki, Y. S., Senem Karahan, S., and K. Yurdakoç. "Kinetic and Thermodynamic Studies of Boron Removal by Siral 5, Siral 40, and Siral 80", J. of Colloid and Interface Sci., 286, 440-446, (2005).

Zollinger, H. "Colour Chemistry: Synthesis Properties and Application of Organic Dyes and Pigments", VCH Publishers, New York, 1991. 